\title{
Health-related quality of life in individuals with genital herpes: a systematic review
}

\author{
Angela Devine ${ }^{1,2+}$, Xiuqin Xiong ${ }^{3 \dagger}$, Sami Lynne Gottlieb ${ }^{4}$, Maeve Britto de Mello ${ }^{4}$, Christopher K. Fairley ${ }^{5}$ and \\ Jason J. Ong $3,5,6,7^{*}$ (D)
}

\begin{abstract}
Background: There is a significant global burden of herpes simplex virus (HSV) related genital ulcer disease yet little is known about its impact on quality of life. This systematic review aimed to identify studies that quantitatively evaluated the effect of genital herpes on various aspects of health-related quality of life.

Methods: Six databases were searched (MEDLINE, EMBASE, NHS Economic Evaluation Database, Health Technology Assessment, Database of Abstracts of Reviews of Effects, Web of Science Core Collection) for primary quality of life and economic evaluations of genital herpes from January 1, 2000 to January 7, 2021. Qualitative studies or those without primary data were excluded. Two authors independently extracted data from the publications. The study's registration number with PROSPERO was CRD42021239410.
\end{abstract}

Findings: We identified 26 relevant publications: 19 presented primary quality of life data, and seven were economic evaluations. The primary studies presented a range of condition-specific tools for describing the quality of life in individuals with genital herpes, but only one study used a direct valuation that could be used to generate utility weights. All economic evaluations of HSV infection were from high-income country settings. Most (6 of 7) focused on neonatal HSV infection with utilities adopted from studies prior to 2000.

Interpretation: The extant literature on genital herpes-related quality of life is limited and requires updating. We recommend future studies be conducted in geographic- and population- diverse settings, and use preference-based condition-specific or generic-instruments to better inform economic modelling.

Keywords: Herpes simplex virus, Quality of life, Systematic review, Genital herpes

\section{Introduction}

An estimated 187 million people aged 15-49 years experienced at least one episode of herpes simplex virus (HSV) related genital ulcer disease in 2016 [1], and 491 million people aged 15-49 living with HSV-2 worldwide [2]. HSV-2 is a sexually transmitted infection that is lifelong, incurable, and can cause recurrent genital ulcer disease and neonatal herpes. Vertically transmitted neonatal

\footnotetext{
*Correspondence: Jason.ong@monash.edu; Jason.Ong@lshtm.ac.uk

${ }^{\dagger}$ Angela Devine and Xiuqin Xiong: Joint first authors

${ }^{3}$ Centre for Health Policy, Melbourne School of Population and Global Health, University of Melbourne, Victoria, Australia

Full list of author information is available at the end of the article
}

herpes is associated with severe morbidity (e.g. long term neurodevelopmental disability) and mortality [3-5]. Genital HSV-2 infection can also increase HIV acquisition and have a significant psychosocial impact on those with the infection.

Given the large burden of HSV-related infection and disease and the lack of available interventions with population prevention impact, the development of vaccines against HSV is an important goal for global sexual and reproductive health [6]. No licensed HSV vaccines currently exist. Over the past decade, several HSV vaccine candidates have been evaluated in early clinical trials [7]; however, the development pipeline has slowed in recent years. Further information on the potential value of HSV original author(s) and the source, provide a link to the Creative Commons licence, and indicate if changes were made. The images or other third party material in this article are included in the article's Creative Commons licence, unless indicated otherwise in a credit line to the material. If material is not included in the article's Creative Commons licence and your intended use is not permitted by statutory regulation or exceeds the permitted use, you will need to obtain permission directly from the copyright holder. To view a copy of this licence, visit http://creativecommons.org/licenses/by/4.0/. The Creative Commons Public Domain Dedication waiver (http://creativeco mmons.org/publicdomain/zero/1.0/) applies to the data made available in this article, unless otherwise stated in a credit line to the data. 
vaccines in terms of their benefits for sexual and reproductive health will be helpful in decision-making related to advancing HSV vaccine development.

Information on the effect of genital herpes on quality of life is needed to determine health state values for decision analytic models; however, herpes-related quality of life has not been well-characterised in many settings globally, particularly in low- and middle-income countries (LMICs). These models are used in cost-effectiveness analyses to enable the efficient allocation of resources. Cost per quality-adjusted life years (QALY) is one popular outcome for cost-effective analyses. QALYs combine life-expectancy and its corresponding healthrelated quality of life, which reflects the impact of mortality and morbidity and can be used to compare across various conditions and interventions [8]. If quality of life information is not available, then cost-effectiveness analyses may need to look at other outcomes, such as HSV infections averted, which are not comparable across disease areas.

In addition to understanding the effects of herpes on quality of life, it is also important to review the instruments available to measure various aspects of quality of life in people living with herpes. These include instruments related to sexual health and well-being, which have been or could be used and validated in populations with genital herpes. In this sense, this review can guide future studies to fill data gaps towards the accurate measurement of genital herpes-related quality of life.

To our best knowledge, a systematic review of healthrelated quality of life in genital herpes has not been undertaken previously. Therefore, the purpose of this systematic review was to identify studies that quantitatively evaluate the effect of genital herpes on various aspects of health-related quality of life and to summarize survey instruments and measurement scales that have been or could be used for measuring quality of life and health utilities in people with herpes.

\section{Methods}

\section{Search strategy and selection criteria}

We conducted a systematic review following guidelines in the Cochrane Handbook to identify studies that quantitatively measure the quality of life for people living with asymptomatic or symptomatic genital herpes [9]. We also included studies that evaluated the impact of the vertical transmission of herpes on the quality of life related to neonatal herpes (both from the mother and neonate's perspectives). The inclusion criteria were studies containing primary data associated with the quality of life in people with herpes, including randomized controlled trials, observational studies, economic evaluations, and primary valuation studies for health utilities.
We excluded qualitative studies or those without primary data. Six databases were searched (MEDLINE, EMBASE, NHS Economic Evaluation Database, Health Technology Assessment, Database of Abstracts of Reviews of Effects, Web of Science Core Collection) on January 7, 2021. The search limits were from 2000-current, humans, and English language (full search strategy in Additional file 1: Appendix pp 2-10). Grey literature was also searched using OpenGrey for potentially useful information. Duplicated articles were excluded using Endnote X9.

We manually searched the reference lists of potentially relevant studies to identify additional studies, and further studies were also added based on our knowledge of the literature. Since few articles were found with our search, articles identified through the reference lists included papers published before 2000. This study was reported following the latest Preferred Reporting Items for Systematic review and Meta-Analysis Protocols (PRISMA) [10]. The study's registration number with PROSPERO was CRD42021239410 (available from https://www.crd. york.ac.uk/prospero/display_record.php?RecordID = 239410).

The studies were first screened by two reviewers independently $(\mathrm{AD}, \mathrm{XX})$, who reviewed all the papers' titles and abstracts and selected the studies that met the inclusion criteria. This process was conducted in Covidence. Any discrepancies were resolved by a third author (JO). Secondly, two reviewers (AD, XX) independently evaluated the full texts of all the selected articles. Abstracts whose full text could not be found but contained useful information were kept for data extraction. All the studies included for data extraction were classified into two groups: economic evaluation studies and primary valuation studies.

\section{Data analysis}

For economic evaluations, data were collected about the study characteristics (author, publication year, year of data collection, country setting), the study population (age, number of participants), the health states and their utility or disutility values, the source of the health utilities, duration of health state, and type of sensitivity analysis used. For primary studies, data were collected about the study characteristics, the study population, methodology used to obtain the utilities (e.g. time-trade off, standard gamble, discrete choice experiments), the health states and their utility or disutility values, and the duration of the health state. The quality assessment of included primary studies was evaluated using a previously developed critical appraisal checklist for healthrelated quality-of-life studies by Picot and colleagues [11], while the quality assessment of economic evaluation studies was evaluated using the methods section of 
the CHEERS checklist[12] by one researcher. The initial assessment was split between two researchers (AD, XX) with a random $30 \%$ checked by a second reviewer (JO). Descriptive statistical analysis was conducted to summarise the study characteristics. Meta-analysis was not conducted because the quality-of-life data came from different instruments with different scales and scoring systems.

\section{Results}

Our search identified a total of 5,406 unique studies; of these, 5,333 were excluded while 73 full texts were assessed for eligibility. After excluding 60 studies and adding 8 studies from scanning references, 21 studies related to genital herpes health-related quality of life were identified. The reasons for the exclusion of studies included not found $(\mathrm{n}=1)$, not relevant (only abstract, no quality of life or utility data, review study) $(n=54)$, and duplication $(\mathrm{n}=5)$. An additional five studies were added from the authors' familiarity with the literature [13-17]. In total, we included seven economic evaluations and 19 primary studies evaluating the health-related quality of life of persons living with genital herpes. Tables 1 and 2 summarise the key demographics of the studies included. Figure 1 presents the PRISMA flowchart.

\section{Economic evaluations of genital herpes}

Table 3 summarises the characteristics of the seven economic evaluation studies. Six studies targeted interventions for pregnant women and neonates [4, 18-23], and one study focused on people with recurrent genital herpes [22]. Two studies examined the cost-effectiveness of serologic testing for HSV infection in pregnant women $[4,19]$. Other studies estimated the cost-effectiveness

Table 1 Overview of included economic evaluation studies

\begin{tabular}{ll}
\hline Primary studies & Total $(\mathbf{N = 1 9 )}$ \\
\hline $\begin{array}{ll}\text { Country income level* } \\
\text { High }\end{array}$ & $\mathrm{n}(\%)$ \\
Middle & $14(88)$ \\
Global & $2(12)$ \\
Populations & $3(3)$ \\
Adults & \\
People living with HIV & $18(95)$ \\
Publication year & $1(5)$ \\
2010 or before & \\
$2011-2021$ & $12(63)$ \\
\hline
\end{tabular}

Table 2 Overview of included primary studies evaluating health-related quality of life of people living with herpes

\begin{tabular}{ll}
\hline Economic evaluation studies & Total $(\boldsymbol{N = 7 )}$ \\
\hline $\begin{array}{ll}\text { Country income level* } \\
\text { High }\end{array}$ & $\mathrm{n}(\%)$ \\
Populations & $7(100)$ \\
Pregnant women and neonates & $6(86)$ \\
Patients with genital herpes & $1(14)$ \\
Publication year & \\
2010 or before & $5(71)$ \\
$2011-2021$ & $2(29)$ \\
\hline
\end{tabular}

*As per the New World Bank current 2021 fiscal year [16]

of testing and treating HS.V infection in neonates with fever [20], of offering prophylactic acyclovir treatment to pregnant women [21], of including treatment of stigma of genital herpes treatment [22], of preventing vertical HSV transmission [18], and of routine antenatal screening for HSV infection [23]. All the economic evaluation studies include QALYs as results. All studies conducted sensitivity analyses.

Table 4 summarises the utilities applied in the health states in the cost-effectiveness studies. All six studies evaluating neonatal HSV infections' health-related quality of life used health state utilities based on the final outcomes of neonatal HSV infection, e.g., mild, moderate or severe disability, and death. Two studies also applied the health state utilities of neonatal HSV infection from the maternal perspective, such as having an impaired child or losing a child $[4,21]$. We only found one study focused on genital herpes that applied a disutility related to stigma and symptomatic recurrence of genital herpes [22].

The seven economic evaluations referenced other literature to obtain their utility weights, with four different sources for neonatal outcomes. Two sources directly valued neonatal HSV infection outcomes [24, 25 ], one source valued the health states of survivors born with extremely low birth weight [26], and one source did not have clear data on HSV related health states [27]. For the same health states, different sources reported different values. The utility for mild neonatal impairment ranged from 0.82 to 1 , moderate impairment ranged from 0.5 to 0.9 , and severe impairment ranges from 0.1 to 0.41 . Notably, all the sources for the neonatal HSV infection outcomes came from studies published before 2000. All utility weights were applied for the duration of life expectancy. Two studies did not report any incidence or probability of developing different outcomes (mild, moderate, severe impairment). 


\section{Identification of studies via databases and registers}

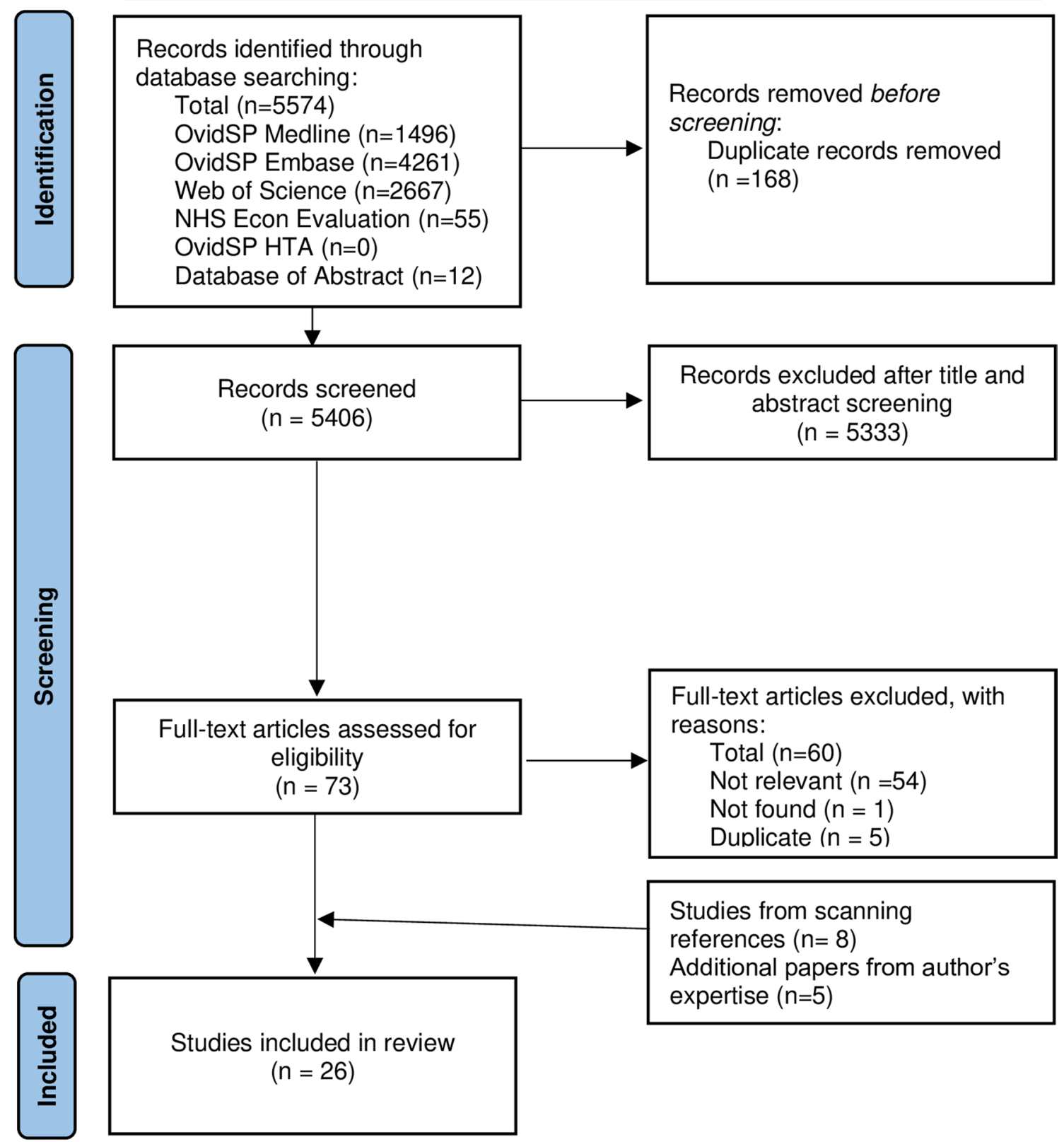

Fig. 1 PRISMA flowchart

\section{Primary studies}

Nineteen primary studies with utility values for herpes were identified by the systematic review (Table 5). Four studies were conducted alongside clinical trials comparing episodic and suppressive therapy [28-31]. The rest of the studies were undertaken to develop herpes-specific quality of life measures [32], evaluate instruments to measure the quality of life in those with genital herpes
$[33,34]$, examine sexual well-being or quality of life [13, $14,34-38]$, and to measure psychosocial responses to a new HSV-2 diagnosis [39, 40].

There were 11 condition-specific instruments found to measure the genital herpes related quality of life, and Recurrent Genital Herpes Quality of Life (RGHQoL) was the most frequently used (6 studies used RGHQoL among total 19). The psychometric properties for these 


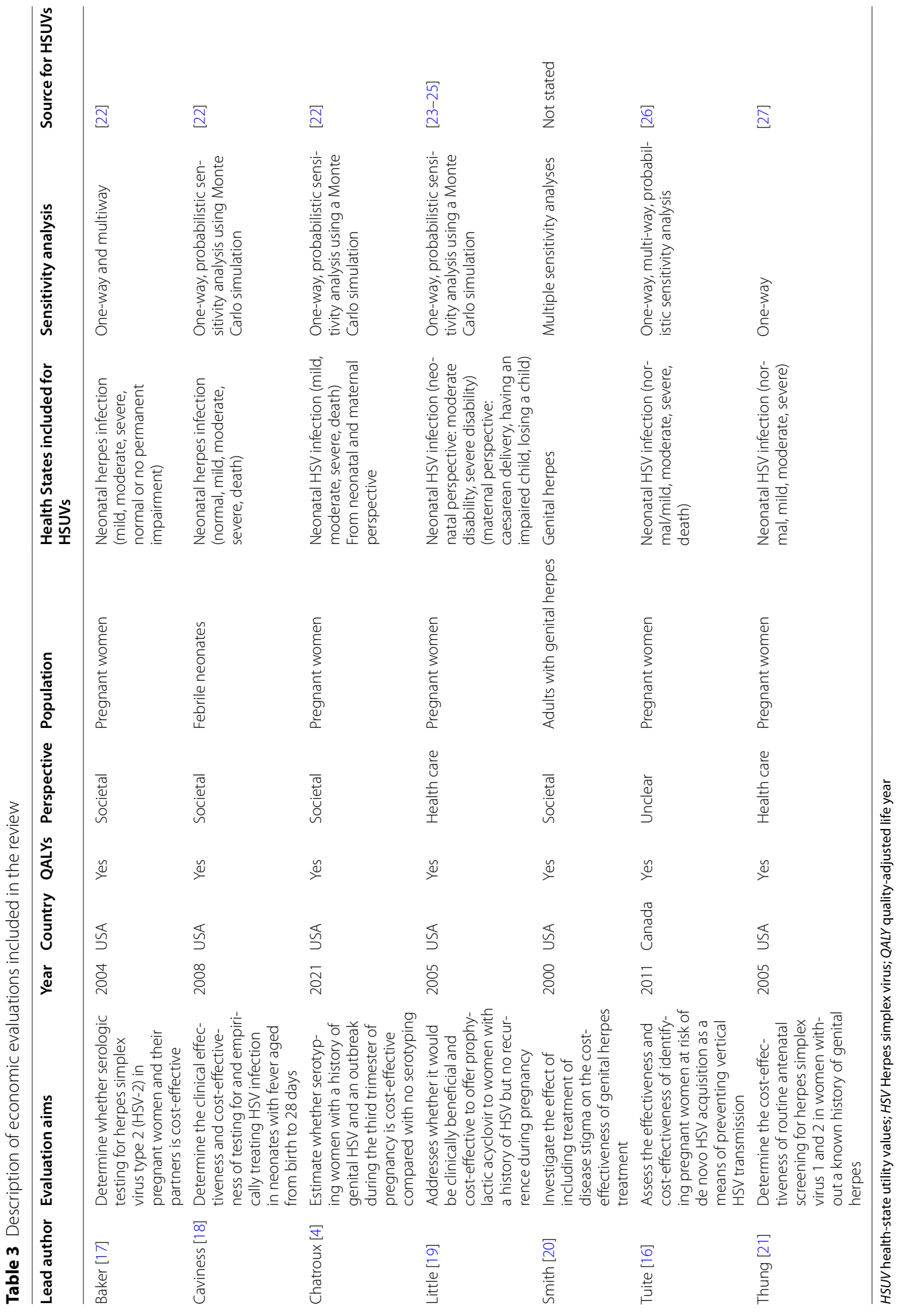


Table 4 Summary of utility values included in economic evaluations for health states

\begin{tabular}{|c|c|c|c|c|c|c|c|c|c|}
\hline \multirow[t]{3}{*}{ Lead author } & \multicolumn{6}{|c|}{ Neonatal HSV infection } & \multicolumn{3}{|l|}{ Genital herpes } \\
\hline & \multicolumn{3}{|c|}{ Neonatal perspective } & \multicolumn{3}{|c|}{ Maternal perspective } & \multirow[b]{2}{*}{ HSUV } & \multirow[b]{2}{*}{$\begin{array}{l}\text { Duration } \\
\text { (years) }\end{array}$} & \multirow[b]{2}{*}{$\begin{array}{l}\text { Probability } \\
\text { of health } \\
\text { state }\end{array}$} \\
\hline & HSUV & $\begin{array}{l}\text { Duration } \\
\text { (years) }\end{array}$ & $\begin{array}{l}\text { Probability of } \\
\text { health state }\end{array}$ & HSUV & $\begin{array}{l}\text { Duration } \\
\text { (years) }\end{array}$ & $\begin{array}{l}\text { Probability of } \\
\text { health state }\end{array}$ & & & \\
\hline \multirow[t]{5}{*}{ Baker [17] } & $\begin{array}{l}\text { No permanent } \\
\text { impairment: } 1\end{array}$ & 76.4 & 0.56 & & & & & & \\
\hline & Mild: 0.82 & 76.4 & 0.05 & .. & .. & .. &.. & .. & .. \\
\hline & Moderate: 0.52 & 76.4 & 0.08 &.$\cdot$ &.$\cdot$ &.. &.$\cdot$ &.$\cdot$ &.$\cdot$ \\
\hline & Severe: 0.16 & 20 & 0.14 &.. &.. & .. &.. &.. &.. \\
\hline & Death: 0 & . & 0.17 &.. &.. & .. &.. & .. & .. \\
\hline \multirow[t]{5}{*}{ Caviness [18] } & Normal: 1 & 77.8 &.$\cdot$ &.$\cdot$ &.. &.. &.. &.$\cdot$ &.$\cdot$ \\
\hline & Mild: 0.82 & 77.8 & \multirow{4}{*}{$\begin{array}{l}\text { Differs according } \\
\text { to treatment } \\
\text { arm, time and } \\
\text { disease state } \\
\text { (e.g., } 12 \text {-month } \\
\text { outcome with } \\
\text { acyclovir therapy } \\
\text { for disseminated } \\
\text { disease: Normal: } \\
\text { 0.28, Mild: } 0.04 \text {, } \\
\text { Moderate: } 0.02 \text {, } \\
\text { Severe: } 0.13 \text {, } \\
\text { Death: } 0.53 \text { ) }\end{array}$} &.. &.. & .. & .. &.. & .. \\
\hline & Moderate: 0.52 & 77.8 & & .. &.. & .. &.. &.$\cdot$ &.. \\
\hline & Severe: 0.16 & 20 & &.$\cdot$ &.$\cdot$ &.. &.$\cdot$ & .. &.. \\
\hline & Death: 0 & & &.. &.. &.. &.. & .. &.. \\
\hline \multirow[t]{4}{*}{ Chatroux [4] } & Mild: 0.82 & 79.3 & $\begin{array}{l}\text { HSV-1: 0.69; HSV- } \\
\text { 2: } 0.49\end{array}$ & Mild: 0.94 & 54.8 & $\begin{array}{l}\text { HSV-1: 0.69; } \\
\text { HSV-2: } 0.49\end{array}$ &.. & .. &.. \\
\hline & Moderate: 0.52 & 79.3 & $\begin{array}{l}\text { HSV-1: 0.01; HSV- } \\
2: 0.14\end{array}$ & Moderate: 0.87 & 54.8 & $\begin{array}{l}\text { HSV-1: 0.01; } \\
\text { HSV-2: } 0.14\end{array}$ &.. &.. &.. \\
\hline & Severe: 0.16 & 20 & $\begin{array}{l}\text { HSV-1: 0.02; HSV- } \\
2: 0.17\end{array}$ & Severe: 0.76 & 54.8 & $\begin{array}{l}\text { HSV-1: } 0.02 ; \\
\text { HSV-2: } 0.17\end{array}$ &.. &.$\cdot$ &.. \\
\hline & Death: 0 &.. & $\begin{array}{l}\text { HSV-1: 0.28; HSV- } \\
2: 0.2\end{array}$ & Death: 0.92 & 54.8 & $\begin{array}{l}\text { HSV-1: } 0.28 \\
\text { HSV-2: } 0.2\end{array}$ &.. &.. &.. \\
\hline \multirow[t]{4}{*}{ Little [19] } & $\begin{array}{l}\text { Normal neonate: } \\
1\end{array}$ & 77.2 & $\#$ & $\begin{array}{l}\text { Caesarean } \\
\text { delivery: } 0.99\end{array}$ & 55.4 & $\begin{array}{l}\text { If lesions pre- } \\
\text { sent at delivery: } \\
1 ; \text { if no lesions } \\
\text { present: } 0.244\end{array}$ &.. &.$\cdot$ &.. \\
\hline & Moderate: 0.9 & 62.0 & $\begin{array}{l}\text { HSV-1: } 0.01, \text { HSV- } \\
2: 0.14\end{array}$ & $\begin{array}{l}\text { Having an } \\
\text { impaired child: } \\
0.81\end{array}$ & 55.4 & Not reported &.. &.. &.. \\
\hline & Severe: 0.3 & 28.7 & $\begin{array}{l}\text { HSV-1: 0.01, HSV- } \\
2: 0.17\end{array}$ & $\begin{array}{l}\text { Losing a child: } \\
0.92\end{array}$ & 55.4 & Not reported &.. &.. &.. \\
\hline & Death: 0 &.. & $\begin{array}{l}\text { HSV-1: } 0.28, \text { HSV- } \\
2: 0.20\end{array}$ & .. & .. &.. &.. &.. &.. \\
\hline \multirow[t]{2}{*}{ Smith [20] } &.$\cdot$ &.. &.$\cdot$ &.$\cdot$ &.$\cdot$ &.. & Stigma: 0.95 & 10 & Unclear \\
\hline &.. & .. &.. & .. & .. &.$\cdot$ & $\begin{array}{l}\text { Symptomatic } \\
\text { recurrence: } 0.90\end{array}$ & 10 & \\
\hline \multirow[t]{4}{*}{ Tuite [16] } & Normal/mild: 1 & 75 & Unclear &.. &.. &.$\cdot$ &.. & .. & .. \\
\hline & Moderate: 0.84 & 38 & Unclear &.$\cdot$ &.$\cdot$ &.. &.$\cdot$ &.$\cdot$ &.. \\
\hline & Severe: 0.41 & 38 & Unclear & .. &.. &.. &.. & .. &.. \\
\hline & Death: 0 &.. & Unclear &.. &.. & .. & .. & .. & .. \\
\hline \multirow[t]{5}{*}{ Thung [21] } & Normal: 1 & 76 & Unclear &.$\cdot$ &.$\cdot$ &.. &.. &.$\cdot$ &.$\cdot$ \\
\hline & Mild: 1 & 76 & Unclear &.. &.$\cdot$ &.. &.. &.$\cdot$ &.$\cdot$ \\
\hline & Moderate: 0.5 & 76 & Unclear &.. &.. &.. &.. &.. &.. \\
\hline & Severe: 0.1 & 76 & Unclear &.$\cdot$ &.$\cdot$ &.. &.. &.$\cdot$ &.$\cdot$ \\
\hline & Death: 0 & & Unclear & .. &.. & .. &.. & .. &.. \\
\hline
\end{tabular}




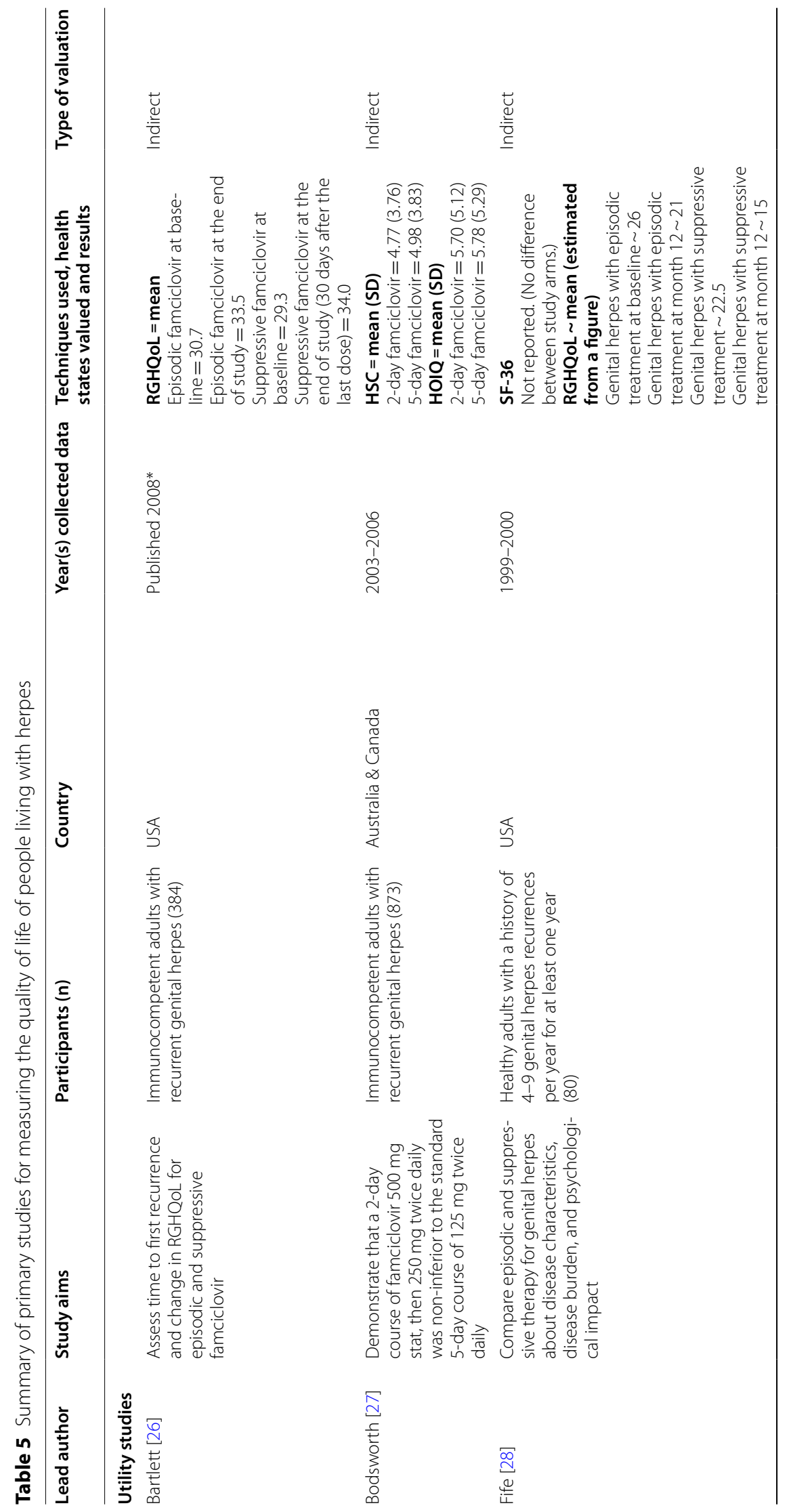




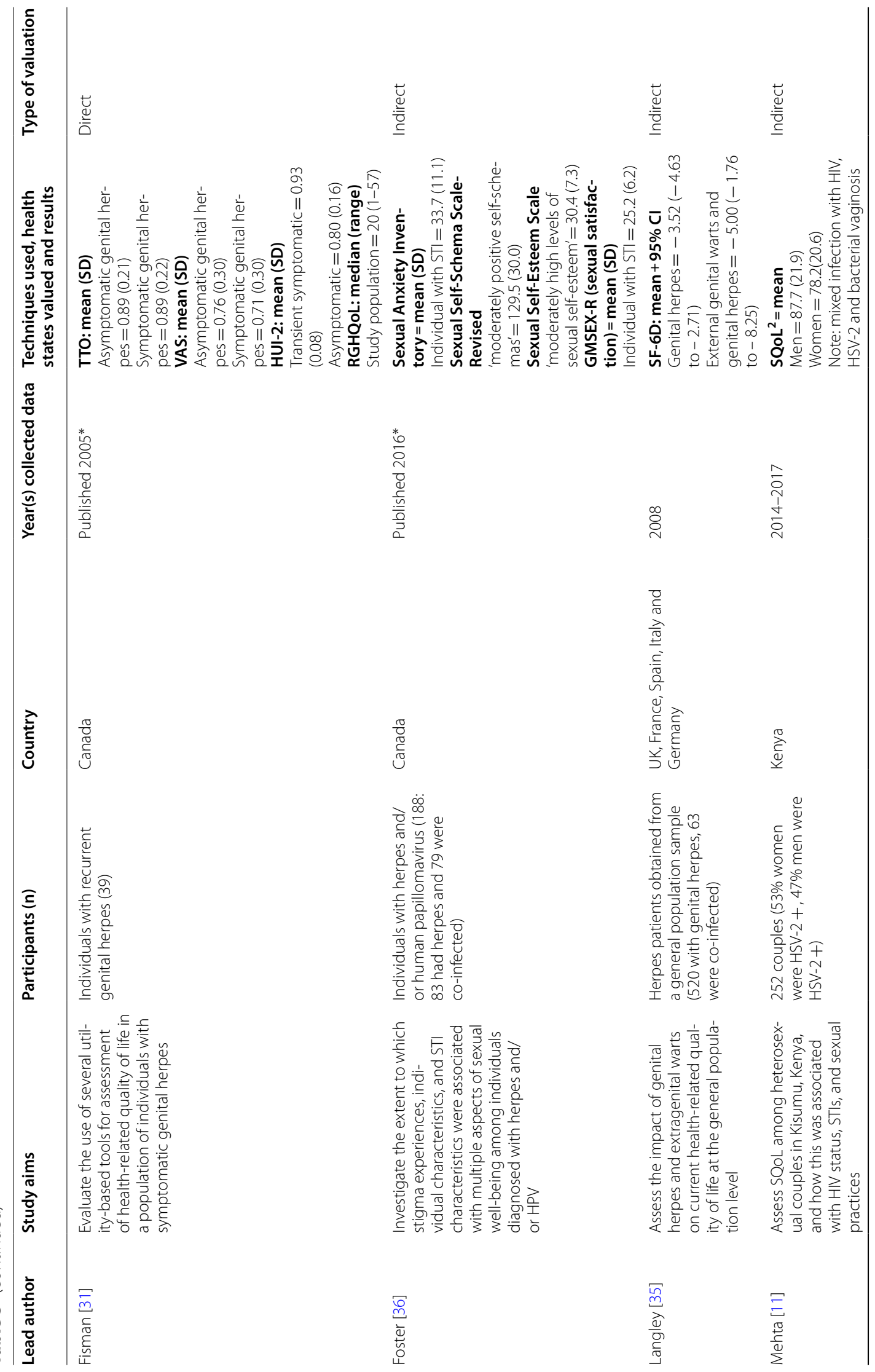




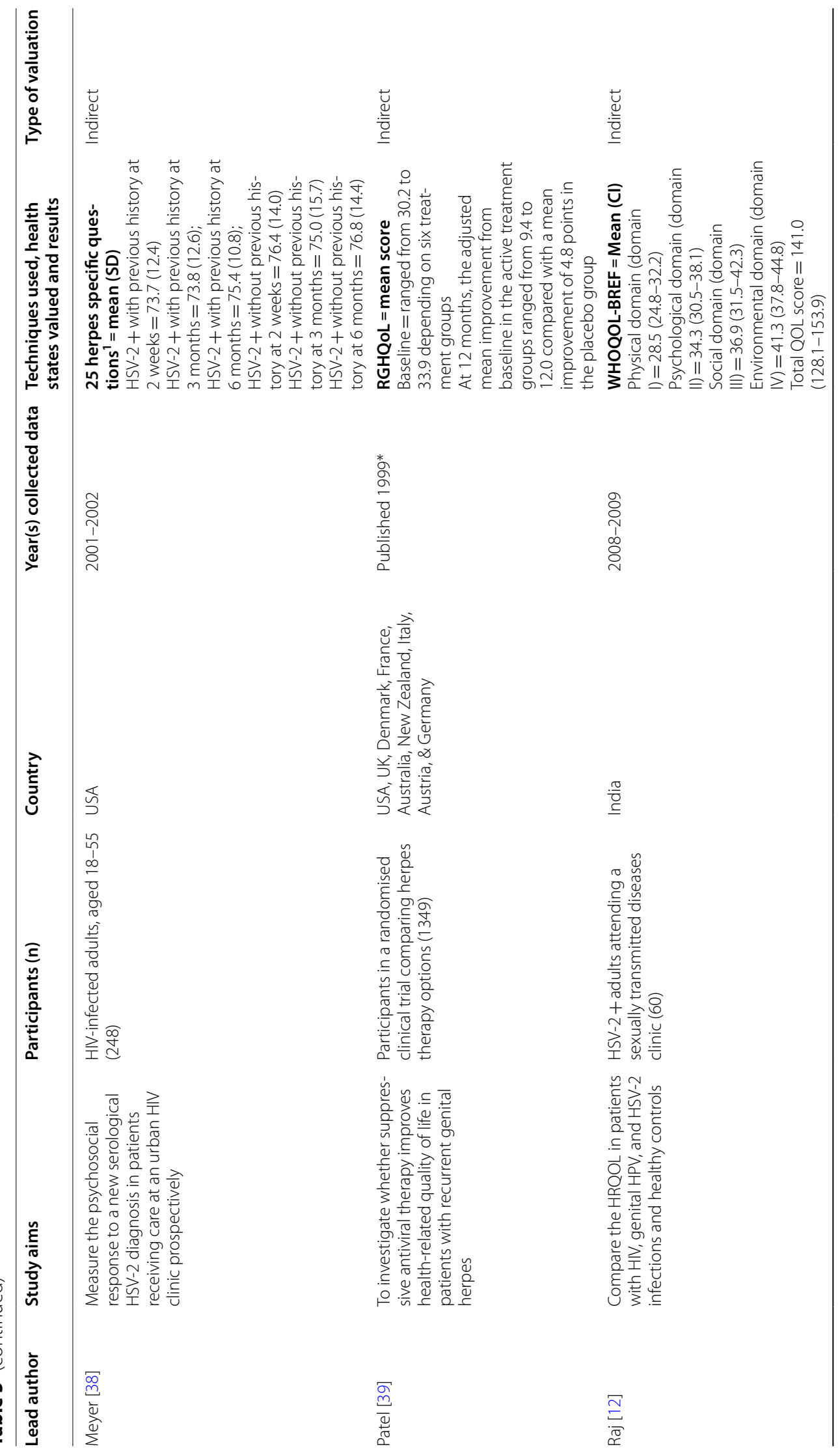




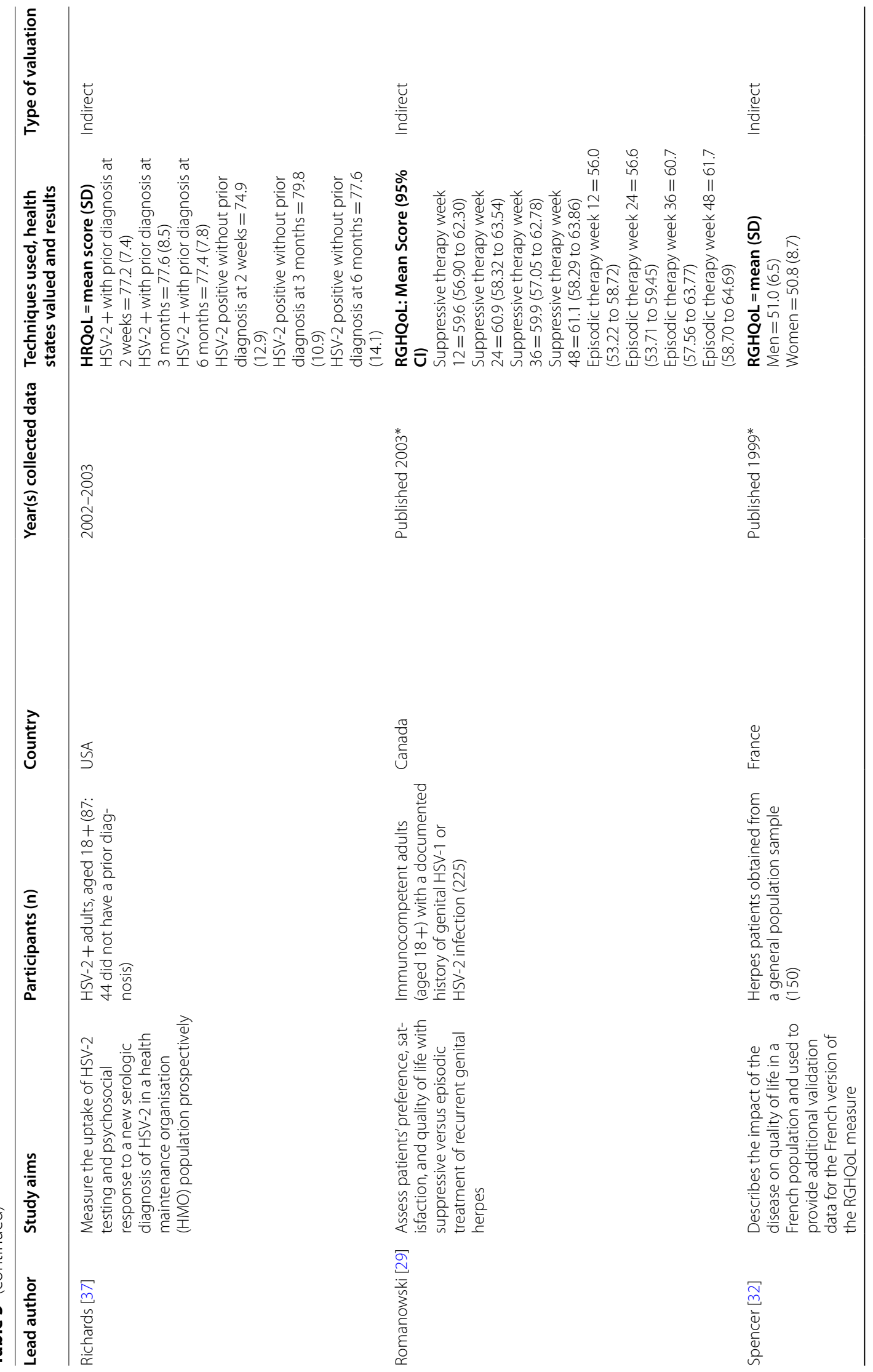




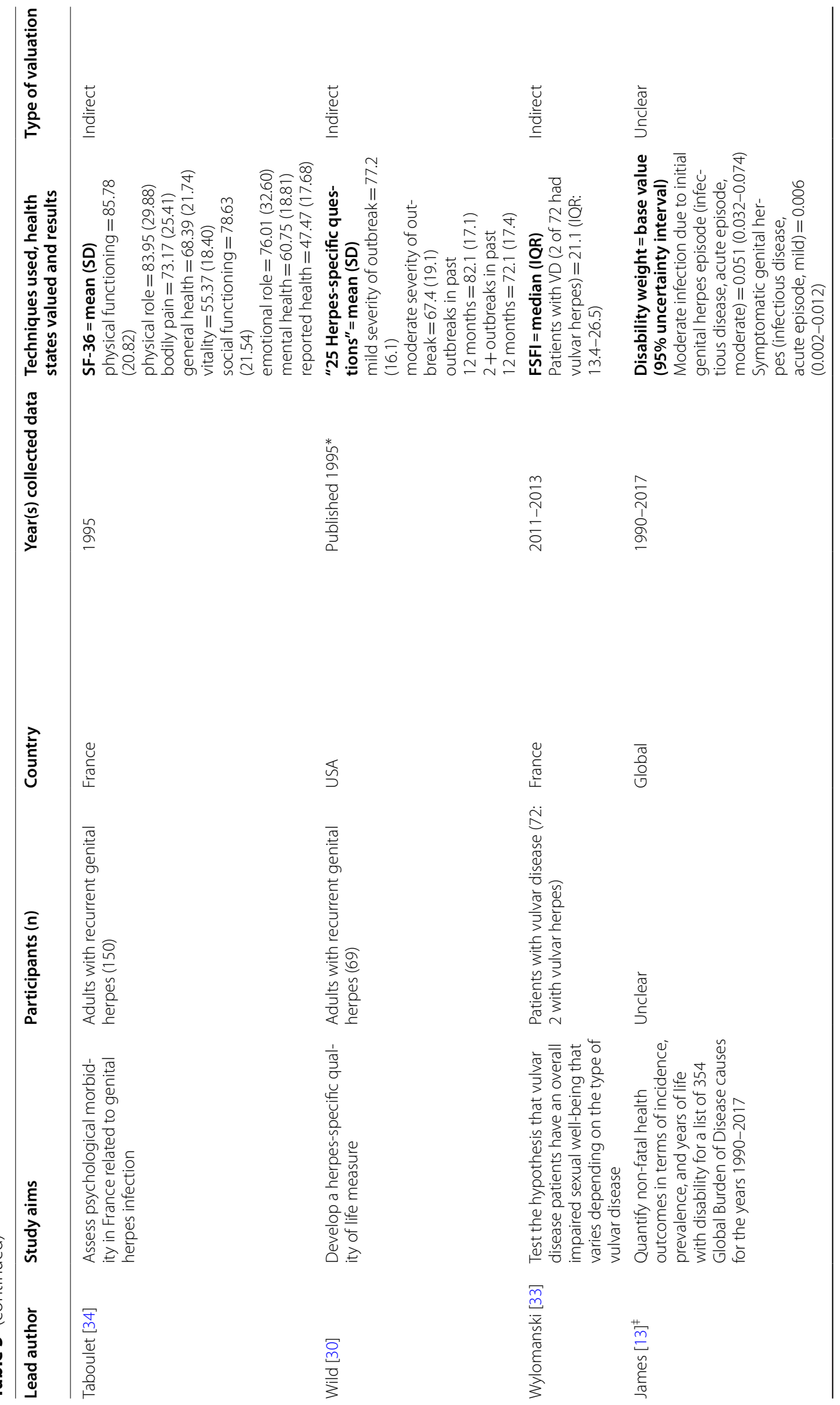




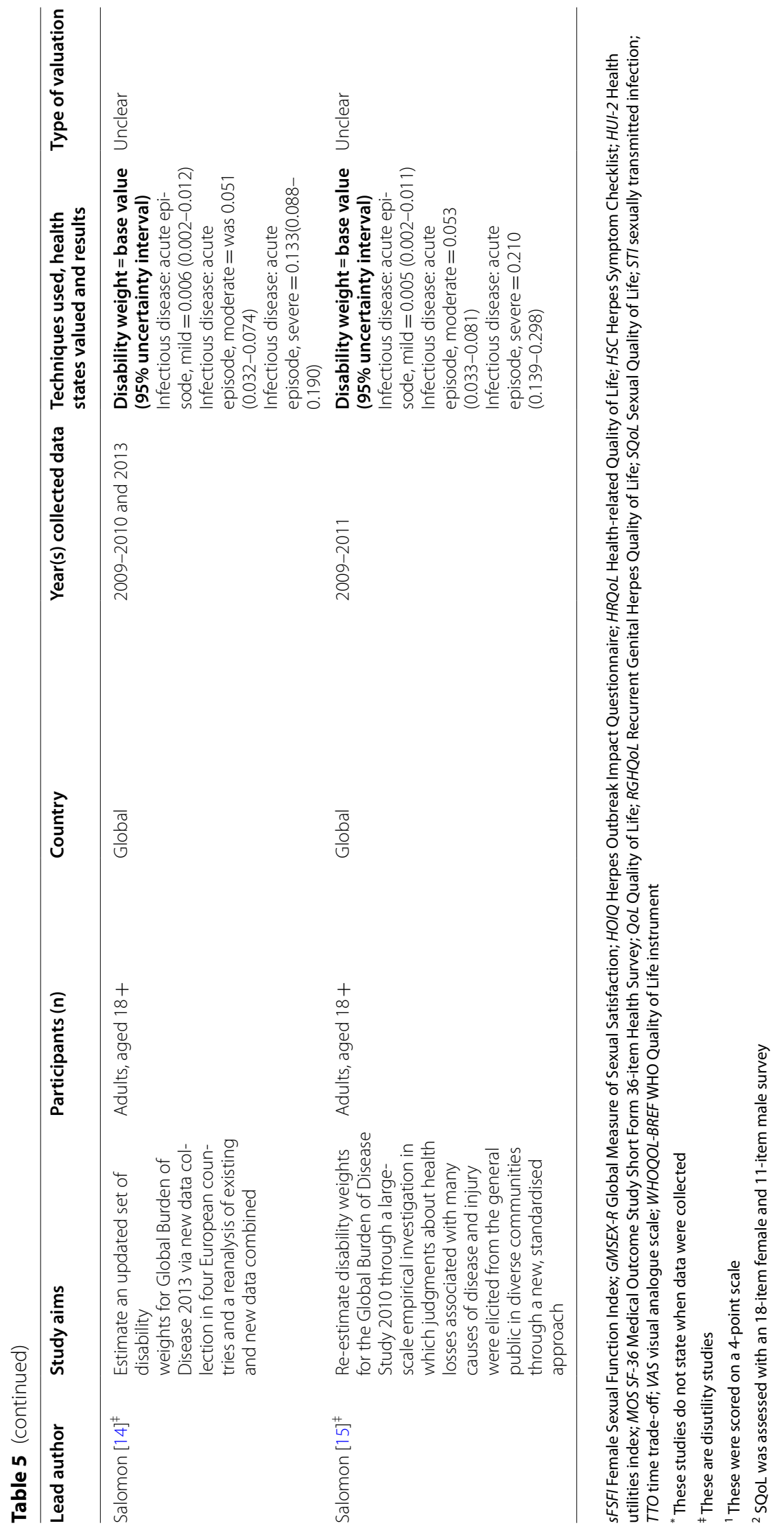


instruments were limited and variable in nature. For example, RGHQoL were shown to have good reliability [41], while Global measure of sexual satisfaction-revised (GMSEX-R) showed high internal consistency [38, 42]. There were some instruments (e.g. Sexual Self-Esteem scale) without any information of psychometric evidence. A more detailed summary of each condition-specific instrument used to measure the quality of life in people living with genital herpes is found in the Additional file 1: Appendix (pp 11-13).

The disability weights of HSV infection related health states came from the Global Burden of Disease (GBD) studies. The most recent GBD study (2017) had disability weights for 'moderate infection due to initial genital herpes episode' as $0.051(0.032-0.074)$, and 'symptomatic genital herpes' as $0.006(0.002-0.012)$ [15]. Previous GBD studies did not have disability weights specific to herpes. In GBD 2013, the disability weights for "infectious disease: acute episode, mild" was $0.006(0.002-0.012)$ while moderate was $0.051(0.032-0.074)$, and severe was 0.133 (0.088-0.308) [16]. The 2010 GBD had mild, moderate, and severe acute episodes as 0.005 (0.002-0.011), $0.053(0.033-0.081)$, and $0210(0.139-0.298)$, respectively [17]. The methods used to derive disutility weights have evolved over time, using data from surveys that began in 2009 using participants who were 18 years and older from a range of countries [16]. The most recent analysis presents 234 health states [15].

Most of the studies were focused on adult populations in Europe and North America except for the GBD studies and two other studies, one from India[14] and one from Kenya [13]. Of the instruments used to assess quality of life, the Recurrent Genital Herpes Quality of Life (RGHQoL) instrument was used the most frequently (six studies) [28, 30, 31, 33, 34, 43]. Many instruments were designed specifically for assessing quality of life in herpes infections and/or sexual health. The most recent study finished collecting data in 2017 [13], but many studies were much older. Six studies had less than 100 participants [14, 30, 32, 33, 35, 39].

The quality assessment of included studies is also found in the Additional file 1: Appendix (pp 14-23).

\section{Discussion}

This systematic review synthesises the available evidence from published studies evaluating the effect of genital herpes on various aspects of health-related quality of life globally. It presents an overview of existing survey instruments and measurement scales that could measure the quality of life and health utilities in people with genital herpes. Only one small study from Canada used direct methods (time trade-off, visual analogue scale) to report a utility weight [33]. Using direct methods or multi-attribute utility instruments are important because they can be directly converted to a utility weight to generate QALYs used in economic modelling.

There is currently no consensus on what utility weights to use for genital herpes related economic evaluations. The source literature used for utility weights in the economic evaluations in this review was all for neonatal HSV infection and published before 2000. Given the paucity of primary studies using instruments that can generate utility weights, we recommend future studies to incorporate generic multi-attribute utility instruments (e.g., SF-6D, EQ-5D) alongside condition-specific instruments or scales (such as RGHQoL) to explore the correlation between these instruments further. This would provide valuable data on the sensitivity and responsiveness of generic utility measurement compared to condition-specific instruments $[44,45]$. Furthermore, a greater diversity of people living with genital herpes is urgently needed for ensuring the health-related quality of life measurements are relevant for different populations. Most primary studies identified in our review were from Europe and North America. The way that populations and subpopulations value various health states can differ significantly across cultures[46] and might change over time.

Almost all primary studies identified by our review used condition-specific quality of life instruments. One example is the RGHQoL, which was the most frequent instrument. The RGHQoL is an instrument with 20 statements to assess the long-term impact on the individuals' quality of life [47]. Patients respond to each statement by indicating the level of their own limitation on a 4-point Likert scale with scores ranging from 0 (maximum limitation) to 3 (minimum limitation). While conditionspecific instruments like the RGHQoL are designed to capture the unique concerns related to genital herpes, the use of these instruments presents challenges if wanting to compare to other diseases in economic evaluations as they are not using a standard preference-based measurement. Only one primary study used direct methods to elicit preferences for a set of utility weights: a study of 39 individuals with recurrent genital herpes in Canada and is now dated (published in 2005) [33]. Accordingly, it is difficult to recommend any utility weights to inform economic evaluations. The best option may be to use the disutility weights from the most recent GBD study, but the methodology on these studies is opaque with sparse information on the survey design and study population.

The information available from the economic evaluations was also limited. First, most were carried out before 2010 and used utilities published before and around 2000 , which is outdated. Second, the evaluations primarily focused on interventions targeting pregnant women; 
with only one economic evaluation for genital herpes [22]. Only two studies included the impact on the mother of having an impaired child or losing a child due to neonatal $[4,21]$. This underscores the importance for future economic evaluations to include the impact of neonatal herpes on parents' quality of life. Furthermore, other important issues such as stigma were only explicitly modelled in one study [22]. Stigma due to herpes infections is a significant source of psychological distress[48] and can also contribute to its spread by deterring disclosure to sexual partners.

Given the current limitations in genital-herpes-related quality of life data, several options exist to improve this knowledge base. Where data using a preference-based measure has not been collected, or the preference-based instrument is not available, a solution may be to "map" or "crosswalk" from other measures of health outcomes. However, directly obtaining utility weights is preferred compared to mapping [49]. Mapping methods are limited by their lack of overlap between the descriptive systems of two measures and do not solve the problem of inadequacy in the descriptive system of the generic measure [50]. Alternatively, developing condition-specific preference-based measures for HSV infection-related diseases have challenges of cross program comparability between different diseases [50], and should be seen only as a supplement to generic preference-based measures [50]. Multiple aspects of quality of life are impacted in people with genital herpes, including physical [51], psychological and social dimensions [52], such as altered perceptions of self-esteem, isolation, fear of rejection and/or genderbased violence, concerns about transmitting the disease, and depression [32]. This information could be used for choosing generic preference-based measurements and the development of condition-specific preference-based measurements.

The strength of this study is that it is the first systematic review to critically appraise the literature on quantitative measurements of the quality of life for individuals with genital herpes. It provides an overview of current knowledge that highlights many existing gaps and thus provides guidance for future research. Several limitations should be noted. Due to the sparse results, we could not conduct a meta-analysis to provide a pooled estimate of utility weight. In addition, the diversity of condition-specific instruments underscored that no consensus has been reached on how to measure the specific impact of genital herpes on quality of life. Lastly, our study excluded nonEnglish literature, so we may have missed data from other geographically diverse populations.

In conclusion, this systematic review identified major gaps in how health-related quality of life for people living with genital herpes is measured. Specifically, there is an urgent need to determine the health-related quality of life for people living with genital herpes and its sequelae from more contemporary populations living in various countries. We also need a better understanding of the determinants and modifying factors of health-related quality of life for people living with genital herpes to provide essential information to support investment in HSV vaccine development.

\section{Supplementary Information}

The online version contains supplementary material available at https://doi. org/10.1186/s12955-022-01934-w.

Additional file 1: Appendices.

\section{Authors' contributions}

SG, MM, JO initiated and designed the review. JO designed the search strategy with contributions from $A D$ and $X X . A D$ ran the search strategy in databases. $X X$ searched the grey literature. $A D$ and $X X$ reviewed search results and extracted the data with support from JO. All authors wrote the first draft and had final responsibility for the decision to submit for publication. All authors read and approved the final manuscript.

\section{Funding}

This study was commissioned by the World Health Organization and funded via support from the US National Institute of Allergy and Infectious Diseases, National Institutes of Health (HQUCN2017628). WHO technical staff were involved in the study design, results interpretation, and decision to submit the study for publication. XX is supported by China Scholarship Council (201906010310). JJO is supported by the Australian National Health and Medical Research Council (NHMRC) Emerging Leadership Investigator Grant (GNT1193955). CKF is supported by an Australian NHMRC Leadership Investigator Grant (GNT1172900).

\section{Availability of data and materials}

All relevant data is provided in this manuscript. Further details can be obtained by contacting the corresponding author.

\section{Declarations}

Ethics approval and consent to participate

This systematic review did not include patient participation and so ethics approval was not required.

\section{Consent for publication}

Not applicable.

\section{Competing interests}

All authors declare no competing interests.

\section{Author details}

${ }^{1}$ Global and Tropical Health Division, Menzies School of Health Research, Charles Darwin University, Darwin, Northern Territory, Australia. ${ }^{2}$ Centre for Epidemiology and Biostatistics, Melbourne School of Population and Global Health, University of Melbourne, Victoria, Australia. ${ }^{3}$ Centre for Health Policy, Melbourne School of Population and Global Health, University of Melbourne, Victoria, Australia. ${ }^{4}$ Global HIV, Hepatitis and STI Programmes, World Health Organization, Geneva, Switzerland. ${ }^{5}$ Central Clinical School, Monash University, Melbourne, Victoria, Australia. ${ }^{6}$ Faculty of Tropical and Infectious Diseases, London School of Hygiene and Tropical Medicine, London, UK. ${ }^{7}$ Melbourne Sexual Health Centre, Carlton, VIC 3053, Australia. 
Received: 17 October 2021 Accepted: 3 February 2022

Published online: 16 February 2022

\section{References}

1. Looker KJ, Johnston C, Welton NJ, James C, Vickerman P, Turner KME, et al. The global and regional burden of genital ulcer disease due to herpes simplex virus: a natural history modelling study. BMJ Glob Health. 2020;5(3):e001875.

2. James C, Harfouche M, Welton NJ, Turner KM, Abu-Raddad LJ, Gottlieb $\mathrm{SL}$, et al. Herpes simplex virus: global infection prevalence and incidence estimates, 2016. Bull World Health Organ. 2020;98(5):315-29.

3. Bhatta AK, Keyal U, Liu Y, Gellen E. Vertical transmission of herpes simplex virus: an update. JDDG Journal der Deutschen Dermatologischen Gesellschaft. 2018;16(6):685-92.

4. Chatroux IC, Hersh AR, Caughey AB. Herpes simplex virus serotyping in pregnant women with a history of genital herpes and an outbreak in the third trimester of pregnancy: a cost-effectiveness analysis. Obstet Gynecol. 2021;137(1):63-71.

5. McPherson CC. Neonatal herpes simplex virus: the long road to improved outcomes. Neonatal Netw. (2):92-8.

6. World Health Organization. WHO preferred product characteristics for herpes simplex virus vaccines [Available from: https://apps.who.int/iris/ bitstream/handle/10665/312344/9789241515580-eng.pdf?ua=1.

7. Gottlieb SL, Giersing BK, Hickling J, Jones R, Deal C, Kaslow DC, et al. Meeting report: Initial World Health Organization consultation on herpes simplex virus (HSV) vaccine preferred product characteristics, March 2017. Vaccine. 2019:37(50):7408-18.

8. Neumann PJ, Cohen JT. QALYs in 2018-advantages and concerns. JAMA. 2018:319(24):2473-4

9. Higgins JP, Thomas J, Chandler J, Cumpston M, Li T, Page MJ, et al. Cochrane handbook for systematic reviews of interventions. Hoboken: John Wiley \& Sons; 2019.

10. Page MJ, McKenzie JE, Bossuyt PM, Boutron I, Hoffmann TC, Mulrow CD, et al. Updating guidance for reporting systematic reviews: development of the PRISMA 2020 statement. J Clin Epidemiol. 2021;134:103-12.

11. Picot J, Copley V, Colquitt JL, Kalita N, Hartwell D, Bryant J. The INTRABEAM ${ }^{\circledR}$ Photon Radiotherapy System for the adjuvant treatment of early breast cancer: a systematic review and economic evaluation. Health Technol Assess. 2015;19(69):1-190.

12. Husereau D, Drummond M, Petrou S, Carswell C, Moher D, Greenberg D, et al. Consolidated Health Economic Evaluation Reporting Standards (CHEERS) statement. BMC Med. 2013;11:80.

13. Mehta SD, Nordgren RK, Agingu W, Otieno F, Odongo W, Odhiambo F, et al. Sexual quality of life and association with hiv and sexually transmitted infections among a cohort of heterosexual couples in Kenya. J Sex Med. 2018;15(10):1446-55.

14. Raj R, Sreenivas V, Mehta M, Gupta S. Health-related quality of life in Indian patients with three viral sexually transmitted infections: herpes simplex virus-2, genital human papilloma virus and HIV. Sex Transm Infect. 2011;87(3):216-20.

15. GBD 2017 Disease and Injury Incidence and Prevalence Collaborators. Global, regional, and national incidence, prevalence, and years lived with disability for 354 diseases and injuries for 195 countries and territories, 1990-2017: a systematic analysis for the Global Burden of Disease Study 2017. Lancet. 2018:392(10159):1789-858.

16. Salomon JA, Haagsma JA, Davis A, de Noordhout CM, Polinder S, Havelaar $\mathrm{AH}$, et al. Disability weights for the Global Burden of Disease 2013 study. Lancet Glob Health. 2015;3(11):e712-23.

17. Salomon JA, Vos T, Hogan DR, Gagnon M, Naghavi M, Mokdad A, et al. Common values in assessing health outcomes from disease and injury: disability weights measurement study for the Global Burden of Disease Study 2010. The Lancet. 2012;380(9859):2129-43.

18. Tuite AR, McCabe CJ, Ku J, Fisman DN. Projected cost-savings with herpes simplex virus screening in pregnancy: towards a new screening paradigm. Sexually Transmitted Infect. 2011;87(2):141

19. Baker D, Brown Z, Hollier LM, Wendel GD, Hulme L, Griffiths DA et al. Cost-effectiveness of herpes simplex virus type 2 serotogic testing and antiviral therapy in pregnancy. Am J Obstet Gynecol. 2004;191(6):2074-84
20. Caviness AC Demmler GJ Swint JM Cantor SB Cost-effectiveness analysis of herpes simplex virus testing and treatment strategies in febrile neonates. Arch Pediatr Adolesc Med. 2008;162(7):665-74.

21. Little SE, Caughey AB. Acyclovir prophylaxis for pregnant women with a known history of herpes simplex virus: a cost-effectiveness analysis. Am J Obstet Gynecol. 2005;193(3 Pt 2):1274-9.

22. Smith KJ, Cook RL, Downs JS, Roberts MS. Cost-effectiveness of management strategies for chronic recurrent genital herpes: a pilot analysis. J Gen Intern Med. 2000;15:4.

23. Thung SF, Grobman WA. The cost-effectiveness of routine antenatal screening for maternal herpes simplex virus- 1 and -2 antibodies. Am J Obstet Gynecol. 2005;192(2):483-8.

24. Mennemeyer ST, Cyr LP, Whitley RJJAJMC. Antiviral therapy for neonatal herpes simplex virus: a cost-effectiveness analysis. Am J Manag Care. 1997;3(10):1551-8.

25. Tengs TO, Wallace A. One thousand health-related quality-of-life estimates. Med Care. 2000;38(6):583-637.

26. Saigal S, Stoskopf BL, Feeny D, Furlong W, Burrows E, Rosenbaum PL, et al. Differences in preferences for neonatal outcomes among health care professionals, parents, and adolescents. JAMA. 1999:281(21):1991-7.

27. Gold MR, Franks P, McCoy Kl, Fryback DG. Toward consistency in costutility analyses: using national measures to create condition-specific values. Medical care. 1998:778-92.

28. Bartlett BL, Tyring SK, Fife K, Gnann JW Jr, Hadala JT, Kianifard F, et al. Famciclovir treatment options for patients with frequent outbreaks of recurrent genital herpes: the RELIEF trial. J Clin Virol. 2008;43(2):190-5.

29. Bodsworth N, Bloch M, McNulty A, Denham I, Doong N, Trottier S, et al. 2-day versus 5-day famciclovir as treatment of recurrences of genital herpes: results of the FaST study. Sex Health. 2008;5(3):219-25.

30. Fife KH, Almekinder J, Ofner S. A comparison of one year of episodic or suppressive treatment of recurrent genital herpes with valacyclovir. Sex Transm Dis. 2007;34(5):297-301.

31. Romanowski B, Marina RB, Roberts JN. Patients' preference of valacyclovir once-daily suppressive therapy versus twice-daily episodic therapy for recurrent genital herpes: a randomized study. Sex Transm Dis. 2003:30(3):226-31.

32. Wild D, Patrick D, Johnson E, Berzon R, Wald A. Measuring healthrelated quality of life in persons with genital herpes. Qual Life Res. 1995;4(6):532-9.

33. Fisman DN. Health related quality of life in genital herpes: a pilot comparison of measures. Sex Transm Infect. 2005;81(3):267-70.

34. Spencer $B$, Leplège A, Ecosse $E$. Recurrent genital herpes and quality of life in France. Qual Life Res. 1999;8(4):365-71.

35. Wylomanski S, Bouquin R, Hanf M, Winer N, Dreno B, Rouzier R, et al. Sexual well-being in patients with vulvar disease: results from a preliminary prospective matched case-control study. Eur J Obstet Gynecol Reprod Biol. 2015;194:106-10.

36. Taboulet F, Halioua B, Malkin JE. Quality of life and use of health care among people with genital herpes in France. Acta Derm Venereol. 1999;79(5):380-4

37. Langley PC, Freedman D, Wagner JS, Gupta S. The experience of external genital warts and genital herpes on quality of life. Value Health. 2010;13(7):A403.

38. Foster LR, Byers ES. Predictors of the Sexual Well-Being Of Individuals Diagnosed With Herpes And Human Papillomavirus. Arch Sex Behav. 2016;45(2):403-14

39. Richards J, Scholes D, Caka S, Drolette L, Magaret AM, Yarbro P, et al. HSV-2 serologic testing in an $\mathrm{HMO}$ population: Uptake and psychosocial sequelae. Sex Transm Dis. 2007;34(9):718-25

40. Meyer JL, Crosby RA, Whittington WL, Carrell D, Ashley-Morrow R, Meier AS, et al. The psychosocial impact of serological herpes simplex type 2 testing in an urban HIV clinic. Sexually Transmitted Infect. 2005;81(4):309-15.

41. Doward LC, McKenna SP, Kohlmann T, Niero M, Patrick D, Spencer B, et al. The international development of the RGHQoL: a quality of life measure for recurrent genital herpes. Qual Life Res. 1998;7(2):143-53.

42. Renaud CA, Byers ES. Positive and negative sexual cognitions: Subjective experience and relationships to sexual adjustment. J Sex Res. 2001;38(3):252-62. 
43. Patel R, Tyring S, Strand A, Price M, Grant DJSti. Impact of suppressive antiviral therapy on the health related quality of life of patients with recurrent genital herpes infection. 1999;75(6):398-402.

44. Richardson J, lezzi A, Khan MA, Chen G, Maxwell A. Measuring the Sensitivity And Construct Validity Of 6 Utility Instruments In 7 Disease Areas. Med Decis Mak. 2015;36(2):147-59.

45. Brazier JE, Rowen D, Mavranezouli I, Tsuchiya A, Young T, Yang Y, et al. Developing and testing methods for deriving preference-based measures of health from condition-specific measures (and other patient-based measures of outcome). 2012;16:32.

46. Gerlinger C, Bamber L, Leverkus F, Schwenke C, Haberland C, Schmidt G, et al. Comparing the EQ-5D-5L utility index based on value sets of different countries: impact on the interpretation of clinical study results. BMC Res Notes. 2019;12(1):18.

47. Doward LC, McKenna SP, Meads DM, Kahler K, Frech F. The Development of the herpes symptom checklist and the herpes outbreak impact questionnaire. Value Health. 2009;12(1):139-45.

48. Merin A, Pachankis JE. The psychological impact of genital herpes stigma. J Health Psychol. 2011;16(1):80-90.

49. Longworth $\mathrm{L}$, Rowen $\mathrm{D}$. Mapping to obtain EQ-5D utility values for use in NICE health technology assessments. Value Health. 2013;16(1):202-10.

50. Tsuchiya A. Preference-based condition-specific measures of health: What happens to cross programme comparability? Health Econ. 2010;19:125-9.

51. Raj R, Sreenivas V, Mehta M, Gupta S. Health-related quality of life in Indian patients with three viral sexually transmitted infections: herpes simplex virus-2, genital human papilloma virus and HIV. Sexually Transmitted Infect. 2011;87(3):216.

52. Taboulet F, Halioua B, Malkin JE. Quality of life and use of health care among people with genital herpes in France. Acta dermato-venereologica. 1999;79(5).

\section{Publisher's Note}

Springer Nature remains neutral with regard to jurisdictional claims in pub-

lished maps and institutional affiliations.

- fast, convenient online submission

- thorough peer review by experienced researchers in your field

- rapid publication on acceptance

- support for research data, including large and complex data types

- gold Open Access which fosters wider collaboration and increased citations

- maximum visibility for your research: over $100 \mathrm{M}$ website views per year

At BMC, research is always in progress.

Learn more biomedcentral.com/submissions 